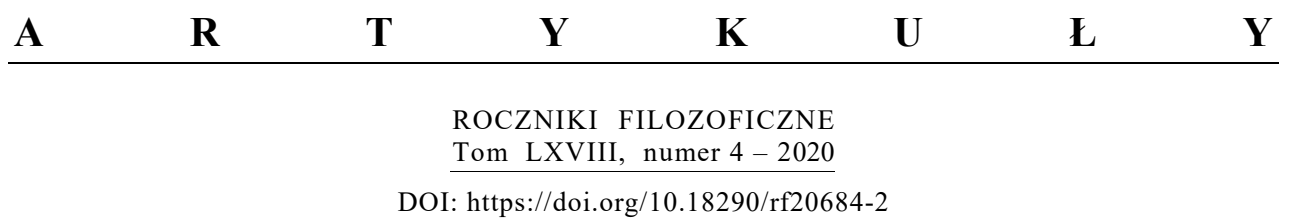

JOHN F. HAUGHT

\title{
CZY NAUKA WYKLUCZA \\ ISTNIENIE OSOBOWEGO BOGA I CZY WIARA W NIEGO JEST KOMPATYBILNA Z EWOLUCJĄ?*
}

Dwie główne części niniejszego tekstu prezentują możliwe odpowiedzi na postawione $w$ tytule dwa pytania. Poszczególne odpowiedzi to trzy różne spojrzenia, nazwane kolejno: konflikt, kontrast, konwergencja. Ostre zarysowanie odmiennych perspektyw, prezentowane przez fikcyjne postacie, pozwala przedstawić odpowiedź w sposób otwarty i prowokujący zarazem.

\section{CZY NAUKA WYKLUCZA ISTNIENIE OSOBOWEGO BOGA?}

\section{KONFLIKT}

Naszą odpowiedzią na stawiane $\mathrm{w}$ tej części pytanie jest stanowcze „tak”1. Nauka wyklucza istnienie osobowego Boga. Jak ktokolwiek wyedukowany może wciąż wierzyć w Boga judaizmu, chrześcijaństwa czy islamu? Nauka nie dostarcza żadnego dowodu na istnienie troskliwego Boga, reagującego na zdarzenia. Nauka sugeruje natomiast, że wszechświat u podstaw jest ślepy, bezrozumny i bezosobowy. Oto zarys naszego stanowiska ${ }^{2}$ :

John F. Haught - Distinguished Research Professor na Wydziale Teologicznym Georgetown University, Washington, DC (USA); haughtj@georgetown.edu.

* Fragmenty książki Science and Faith: A New Introduction by John F. Haught, copyright (C) 2012 by John F. Haught, Paulist Press, New York / Mahwah, NJ. Wykorzystane za zgodą wydawnictwa Paulist Press (www.paulistpress.com).

${ }^{1}$ „Konflikt” wyraża stanowisko scjentystyczne i naukowy naturalizm.

${ }^{2}$ Por. Charley Hardwick, Events of Grace: Naturalism, Existentialism, and Theology (Cambridge: CUP, 1996). 
1. Nie istnieje nic poza naturą, do której należą ludzie i wytwory ich kultury, takie jak język czy sztuka. Nie ma żadnych dowodów na istnienie Boga, duszy czy życia po śmierci. Natura jest wszystkim co istnieje, a najlepszym sposobem na jej zrozumienie jest nauka.

2. Skoro nie istnieje osobowy Bóg, świat przyrody musiał powstać samorzutnie. Świat nie ma innego wyjaśnienia niż on sam. Wszechświat „po prostu jest".

3. Wszechświat nie ma celu. Nauka nie znalazła żadnego świadectwa na to, że cokolwiek o trwałej doniosłości dzieje się w świecie. Kosmos ma długą historię, ale to historia bez znaczenia. Wszystko, włączywszy w to osiągnięcia ludzkości, zniknie w finalnym wielkim kosmicznym mrozie, jak uważa współcześnie większość kosmologów. Nie ma więc żadnego dobrego uzasadnienia dla wiary w osobowego Boga, który nadaje trwałe znaczenie twemu życiu czy kosmicznej historii. Możesz jednak sam nadać sens swojemu życiu.

4. Ponieważ Bóg nie istnieje, wszystko, co dzieje się w świecie, włączywszy w to wszelką aktywność intelektualną, dobre uczynki a nawet religijne tęsknoty (jeśli masz takie), są w pełni naturalne i mogą być całkowicie wyjaśnione przez naukę.

5. Dobre postępowanie nie wymaga wiary w Boga, który decyduje o tym, co jest dobre lub złe, który nagradza lub karze. Ludzie potrafią sami rozpoznać, co jest dobre, a co złe. Współczesna nauka wyjaśnia, jak możemy być dobrymi bez Boga.

Przyznajemy, że przed erą nauki łatwiej było wierzyć w Boga niż dziś. Nie jest zaskoczeniem, że ludzie nieznający nauki wciąż wyjaśniają zjawiska w przyrodzie przypisując je działaniom bóstw lub osobowego Boga. Przytrafiające się ludziom dobre rzeczy wydają się być darami dobrych duchów, zaś złe - takie jak burze, powodzie, trzęsienia ziemi, tsunami, susze, zarazy czy głód, są odbierane jako boża kara za grzech.

Nauka jednak zdesakralizowała świat, przeganiając bożki na dobre. Po naukowym zbadaniu zjawisk przyrodniczych zrozumieliśmy, że stoi za nimi wyłącznie bezrozumna materia. Wszystko można zredukować do cząstek atomowych i procesów fizycznych. Im nauka głębiej wnika, tym bardziej bezosobowy świat odkrywa. Jak słusznie zauważył Steven Weinberg, fizyk i ateista, świat nie zawiera żadnych śladów ,zainteresowanego" nim Boga ${ }^{3}$. Prawdą jest, że sposób rozumienia praw przyrody prezentowany dawniej

\footnotetext{
${ }^{3}$ Steven WeinBerg, Dreams of a Final Theory (New York: Pantheon Books, 1992), 241-261.
} 
przez fizyków mógł sugerować istnienie odległego boskiego prawodawcy. Jednak od czasów Izaaka Newtona (1642-1727) nauka coraz bardziej pokazywała, że wszystko, co dzieje się na świecie, może być wyjaśnione przez ślepe prawa chemii i fizyki. Światowej sławy kosmolog Stephen Hawking niedawno słusznie argumentował, że bezosobowe prawa przyrody są zupełnie wystarczające do wyjaśnienia tego, jak zaistniał wszechświat. Kosmologia Wielkiego Wybuchu czyni ideę stworzyciela zbędną ${ }^{4}$. Mając na uwadze współczesną fizykę i kosmologię, doszukiwanie się w wyraźnie bezrozumnie funkcjonującej przyrodzie nieskończonej boskiej miłości, przyjaznej twarzy czy wiecznej troskliwej opatrzności wydaje się głupie.

Nie tylko fizyka, ale także biologia wspierają nasze naturalistyczne odrzucenie osobowego Boga. Na początku XX wieku niektórzy religijni naukowcy, tęskniący za mistycyzmem, wymyślili sobie, że żyjące organizmy powstały z martwej materii w cudowny sposób. Zakładali, że tylko żyjący Bóg mógł tchnąć życie w kosmos. Jednak do końca XX wieku biochemia i biologia molekularna wykazały, że sekret życia tkwi w interakcjach dużych molekuł, znanych jako amino- i nukleo- kwasy. Witalizm - pogląd głoszący, że niematerialna siła wniosła życie do wszechświata - jest dziś anachronizmem. Nie ma nic nadzwyczajnego czy cudownego w zjawisku życia. Poszczególne cechy żywych organizmów, w tym ludzi, mogą być dziś w zupełności uznane za skutek działania tego, co biologia nazywa „naturalną selekcją".

Być może chcesz zastrzec, jak czyni to wielu wierzących ludzi nieznających nauki, że złożoność życia jest tak oszałamiająca, iż wymaga inteligentnego projektanta. Możesz też przypuszczać, że istnienie ludzkiej świadomości jest tak niesamowicie nieprawdopodobne, iż tylko rozumny Bóg mógł ją stworzyć. Tymczasem biologia i nauki kognitywne, w tym neuronauka, psychologia ewolucyjna i studia nad sztuczną inteligencją, są dziś na tyle zaawansowane, że możemy przypuszczać, iż ludzka świadomość, łącznie z tym co nazywamy „osobowością”, zostanie ostatecznie wyjaśniona przy użyciu samych metod naukowych.

Możesz wciąż nie być przekonanym, co do tego, że twój własny umysł mógł powstać bez wpływu boskiej inteligencji. Możesz powtarzać za psalmistą: „Nie ma usłyszeć Ten, który ucho wszczepił, nie ma widzieć Ten, co utworzył oko" (Ps 94,9-10). Przez analogię możesz zapytać, czy nie potrzeba boskiej inteligencji do stworzenia ludzkiej?

\footnotetext{
${ }^{4}$ Stephen Hawking, Leonard MLodinow, The Grand Design (New York: Bantam Books, 2010).
} 
Otóż nie trzeba. Nauka dostarcza nam czysto naturalne wyjaśnienie istnienia i działania naszego umysłu. W swojej erudycyjnej książce Consciousness Explained filozof Daniel Dennett, jeden z najbardziej szanowanych współczesnych obrońców konfliktu, przekonująco dowodzi, że twoja świadomość nie jest bardziej tajemnicza czy mniej fizykalna niż jakikolwiek inny proces fizyczny ${ }^{5}$. Za twoją osobowością stoi bezosobowy wszechświat. Twoje ciało kreuje świadomość za pomocą mózgu i systemu nerwowego w tak samo naturalny sposób, jak twój żołądek trawi pokarm.

Oczywiście nauka nie wyjaśniła jeszcze wszystkich szczegółów związanych ze świadomością, ale wierzymy, że ostatecznie dokona tego. Nauka potrzebuje czasu i prędzej czy później obali staroświeckie przekonanie o odrębności umysłu od mózgu, istnieniu nieśmiertelnej duszy czy swojego „ja”. Wówczas stanie się jasne, że istnienie osobowego Boga nie jest potrzebne do wyjaśnienia twojej własnej inteligencji czy osobowości. One powstały w wyniku procesów ewolucyjnych trwających miliony lat, w bezmyślnym wszechświecie. Twoi przodkowie, naukowi ignoranci, dokonywali projekcji swojej własnej osobowości na bezosobowy wszechświat i to życzeniowe myślenie doprowadziło do powstania idei osobowego Boga. Dziś nauka nakazuje nam raz na zawsze odrzucić te dziecinne wizje.

Najbardziej uznany naukowiec XX wieku, Albert Einstein, wspierał nasz sprzeciw wobec idei osobowego Boga. Prawdą jest, że czasem mówił o „Bogu”, a nawet publicznie określał siebie jako człowieka religijnego ${ }^{6}$. Jednak był on religijny tylko w tym sensie, że miał poczucie istnienia czegoś pozostającego tajemnicą wszechświata, oraz że istnieje sfera stałych wartości, którym naukowiec winien się poświęcić. Jednocześnie zdecydowanie odrzucał wiarę w osobowego, troskliwego Boga Żydów, chrześcijan czy muzułmanów. Uważał, że idea Boga, który może odpowiedzieć na modlitwy jest efektem pierwotnych zabobonów. Taka wiara, zdaniem Einsteina, jest głównym źródłem konfliktów między nauką i religią. Kiedy więc mówił, że „Bóg nie gra ze światem w kości”, miał na myśli to, iż wszechświatem rządzą nienaruszalne, bezosobowe prawa fizyki. Sporadyczne używanie słowa „Bóg” przez Einsteina mogło sugerować niektórym czytelnikom jakiś rodzaj teizmu, jednakże używał on teologicznego języka tylko po to, aby podkreślić swoje przekonanie o inteligibilności i wieczności wszechświata, rządzonego swoimi własnymi prawami. Tak jak jego intelektualny mentor,

\footnotetext{
${ }^{5}$ Por. Daniel C. Dennet, Consciousness Explained (New York: Little, Brown and Co., 1991).

${ }^{6}$ Albert Einstein, Ideas and Opinions (New York: Crown Publishers, 1954), 11.
} 
filozof Baruch Spinoza (1632-1677), Einstein był przekonany, że przyroda jest wszystkim, co istnieje. My, prezentujący stanowisko konfliktu, zgadzamy się z tym w zupełności.

\section{KONTRAST}

Teraz proszę sobie wyobrazić grupę ludzi reprezentujacych drugie stanowisko, którzy z moca mówia bezpośrednio do ciebie.

Mamy ważne pytanie do naukowych sceptyków, których opinię właśnie usłyszałeś: czy to naprawdę nauka wyklucza istnienie osobowego Boga? Czy może raczej dzieje się to przez scjentyzm i wynikający z niego naukowy naturalizm? Czy to nie te poglądy, a nie nauka sama w sobie, są sprzeczne $\mathrm{z}$ teologią?

Scjentyzm definiujemy jako przekonanie, że nauka jest jedyną drogą do poznania prawdy, zaś naukowy naturalizm jako przekonanie, że istnieje wyłącznie świat przyrody, dostępny naukowemu poznaniu. Podkreślamy, że scjentyzm i naukowy naturalizm nie są tożsame z nauką i stanowią nieuprawnione założenia. W naszej opinii między nauką i wiarą istnieje kontrast, ale nie konflikt. Konflikt występuje między dwoma systemami przekonań: teistyczną wiarą i scjentyzmem, prowadzącym do naukowego naturalizmu.

Mamy zatem pytanie do Weinberga, Hawkinga i Einsteina: czy wasze kompetencje w dziedzinie fizyki i kosmologii dają wam uprawnienia do decydowania o racjonalności wiary w osobowego Boga? Zadajemy to pytanie, ponieważ wszystkie nauki przyrodnicze $\mathrm{z}$ definicji nie zajmują się tym, co odnosi się do Boga. Nic zatem dziwnego, że nauka nie może znaleźć Boga. Metodą naukową nie da się wykryć jakichkolwiek znaków boskości, nawet jeśli Bóg istnieje. Prawdziwa nauka z satysfakcją przedstawia swoje rozumienia świata za pomocą abstrakcyjnych modeli i matematycznych równań. Nauka ogranicza sama siebie do bezosobowego, beznamiętnego opisu świata przyrody. Fizyka próbująca podejmować problem istnienia osobowego Boga byłaby karykaturą samej siebie.

Kwesta istnienia osobowego Boga jest zatem poza zasięgiem fizyki czy którejkolwiek z nauk przyrodniczych. Dlatego podkreślamy, że żywione przez Hawkinga, Weinberga czy Einsteina przekonanie o rzekomej bezosobowości wszechświata nie ma oparcia w nauce, ale jest wymysłem scjentyzmu. Co więcej, w naszej opinii wyznawcy scjentyzmu są tak samo religijni jak ich przednaukowi poprzednicy. Scjentyzm i naukowy naturalizm dostarczają bowiem odpowiedzi na odwieczne religijne pytania: skąd przycho- 
dzimy? jaka jest nasza prawdziwa tożsamość? czy istnieje coś stałego i nieprzemijającego? jaki jest ostateczny cel wszystkiego?

Powyższe pytania nie są naukowe, lecz religijne. Nawet jeżeli odpowiedzi dawane przez scjentyzm czy religijny naturalizm są wzniosłe, stanowią system przekonań czy światopogląd wykraczający poza to, co nauka może powiedzieć. Naukowy naturalizm podejmuje odwieczne religijne pytania ludzkości, ale czyni to redukując najpierw rzeczywistość do wymiaru fizycznego, materialnego. To podejście nazywane bywa „redukcjonizmem” i prowadzi do naturalistycznego światopoglądu, określanego jako „materializm” lub „fizykalizm”. Wydaje się nam, że jasność i mierzalność, razem z przekonaniem o mocnej realności materii, odwołują się do głębokiej mistycznej tęsknoty za złączeniem jednostkowego umysłu i życia w pewną podstawową jedność - w tym wypadku w nierozumną materię.

Materializm, czyli pogląd, że realnie istnieje tylko materia, odpowiada nie tylko na marzenie umysłu o prostocie świata, ale również na ludzką tęsknotę za mocną i trwałą podstawą, na której można oprzeć przemijające i pełne lęku życie. Co więcej, materialistyczny sen o wyczerpującym fizycznym wyjaśnieniu wszechświata funkcjonuje na zasadzie świętego Graala scjentystycznej wersji ludzkiej tęsknoty za pełnią oświecenia. Nadzieja na pełnię poznania za pomocą nauki każdego poranka motywuje scjentystycznych materialistów do wstania z łóżka. To właśnie ten zbiór przekonań, a nie nauka, stoją w opozycji do wiary w osobowego Boga.

We współczesnym świecie naukowym, scjentyzm tak silnie związał się z wieloma uznanymi koncepcjami, że często trudno rozdzielić jedno od drugiego. Publikacje otwarcie ateistycznego ewolucjonisty Richarda Dawkinsa są tego szczególnym przykładem ${ }^{7}$. Pisał on: „Być może ludzkość nigdy nie osiągnie pełni zrozumienia wszechświata. Jestem jednak przekonany, że jeśli się to uda, będzie to zasługa nauki, a nie religii. Jeśli to brzmi jak scjentyzm, tym lepiej dla scjentyzmu" ". Dawkins nie jest odosobniony w swym gorliwym religijnym oddaniu scjentyzmowi. Alex Rosenberg, dziekan wydziału filozofii Duke University, wyraził credo wielu współczesnych filozofów, naukowców i dziennikarzy, opisując scjentyzm jako „filozoficzną teorię, która traktuje naukę jako najbardziej wiarygodne źródło wiedzy, a metodę naukową jako najbardziej skuteczną drogę poznania"9.

\footnotetext{
${ }^{7}$ Niemalże na każdej stronie The God Deluson Dawkins przeskakuje między nauką a scjentyzmem, niemal zawsze bez zaznaczenia tej zmiany.

${ }^{8}$ Richard Dawkins, „Tanner Lecture on Human Values” (wykład wygłoszony na Harvard University, 19-20.11.2003).

${ }^{9}$ Alex Rosenberg, „Why I Am a Naturalist”, New York Times, 17.09.2011.
} 
Scjentyzm, pomimo braku naukowych podstaw, jest bardzo wpływowy wśród naukowców i intelektualistów. Jako zwolennicy kontrastu mamy jednak więcej szacunku dla integralności nauki niż wyznawcy scjentyzmu. Precyzyjnie oddzielamy naukę nie tylko od teistycznej wiary, lecz także od wszelkich systemów przekonań, w tym od scjentyzmu i materializmu. Naiwne mieszanie nauki i scjentyzmu, prezentowane przez Dawkinsa i Rosenberga, doprowadziło wielu współczesnych intelektualistów do całkowicie nienaukowej tezy o niemożliwości pogodzenia nauki i teologii. Uważamy jednak, że nie ma żadnej sprzeczności między czystą nauką a prawdziwą teologią. Ani metoda naukowa, ani naukowe odkrycia, nie są też sprzeczne z ideą osobowego Boga.

Gdy przedstawiamy nasze podejście, kontrast, i mówimy o osobowym Bogu, nie odnosimy się do iluzorycznych idei błąkających się bez celu po bezdrożach ludzkiej wyobraźni. Mówimy o silnych doświadczeniach podobnych do tych i nie mniej realnych niż te, które wywołuje spotkanie jednej osoby w drugą. Odnosimy się do doświadczenia boskiego „Ty”, które kieruje się do nas, nawiązuje więź i skłania do osobowej przemiany bardziej, niż jakiekolwiek inne doświadczenie w naszym życiu. Doświadczenie Boga przychodzi nie przez bezosobową metodę naukową, ale przez wyjątkowo międzyosobowy stan świadomości.

Czciciele scjentyzmu powiedzą na to rzecz jasna, że nie powinniśmy wierzyć w nic, na co nie ma wystarczających dowodów naukowych. Mamy dwojaką odpowiedź na to zastrzeżenie. Po pierwsze, jak już wskazaliśmy, nie ma żadnego naukowego dowodu na rzecz scjentyzmu. Jest on przekonaniem, które nie ma z nauką nic wspólnego, poza tym, że wyolbrzymia on skuteczność i zakres naukowych poszukiwań. Po drugie, co ważniejsze, kto może powiedzieć, że nie ma żadnych dowodów stojących za naszych zaufaniem osobowemu Bogu?

Istnieją dwa rodzaje dowodów. Pierwsze możemy określić jako „dowody obserwacyjne". Jest to rodzaj dowodów zbieranych za pomocą zmysłowego doświadczenia lub dzięki narzędziom obserwacyjnym jak mikroskop czy teleskop. Takich dowodów poszukuje nauka ${ }^{10}$.

Istnieją jednak także „dowody transformatywne”. Spotykasz je każdego dnia podczas kontaktów z innymi osobami. Przecież doświadczyłeś intymnej więzi międzyosobowej z przyjaciółmi czy z innymi ludźmi, którzy cię kochają, są dla Ciebie wyzwaniem, zmieniają Cię, często w sposób zasadniczy.

\footnotetext{
${ }^{10}$ Paul K. Moser, The Elusive God: Reorienting Religious Epistemology (New York: CUP, 2008), 53-54.
} 
Dowodów ze zmiany możesz doświadczyć jedynie stając się wrażliwym na życie wewnętrzne lub podmiotowość innych osób. Gdy mówimy o doświadczeniu osobowego Boga mamy na myśli coś podobnego do tego, co się dzieje, gdy pozwalasz innemu osobowemu podmiotowi obdarzyć cię miłością. Ten rodzaj dowodu radykalnie zmienia twoje życie, gdy go doświadczasz. Dlatego uważamy, że wiara w osobowego Boga oparta jest na dowodzie ze zmiany, nie zaś na czysto naukowym czy obserwacyjnym.

Przemieniające doświadczenie, które wiążemy $\mathrm{z}$ wiarą $\mathrm{w}$ osobowego Boga, czasem ma miejsce w intymności naszego osobistego życia, ale może też zajść za pośrednictwem wspólnoty lub tradycji, powiązanych z określonym zbiorem religijnych wyobrażeń, rytuałów i opowieści. Jesteśmy przekonani, że wymyka się to poszukiwaniom dowodów obserwacyjnych, stanowiących podstawę naukowych koncepcji. W ogóle nie potrzebujemy pomocy bezosobowej, obiektywizującej nauki do potwierdzenia naszego poczucia, że osobowy Bóg zwraca się do nas. Doświadczenie wiary dokonuje się całkowicie poza tym, co nauka może rozjaśnić.

Żądanie naukowego uzasadnienia naszej wiary przez przedstawicieli konfliktu, sceptyków takich jak Dawkins i inni przedstawiciele Nowego Ateizmu, jest więc głęboko niedorzeczne. Można je porównać z oczekiwaniem naukowego dowodu tego, że ktoś się w tobie zakochał. Nie szukaliśmy spotkania z Bogiem. Często też próbowaliśmy uciec od niego, bojąc się, że będzie to nas mobilizować do głębszego przeżywania naszego życia. Osobista przemiana wymagana przez wiarę nie jest prosta i mało kosztowna. Wielu z nas czasem usiłuje uniknąć wymagań stawianych przez wiarę. Możliwe nawet, że usprawiedliwienie dla takiej postawy znajdujemy w scjentyzmie, który skłania nas do interpretowania wiary jako niczego więcej niż życzeniowe myślenie. Wielu jednak odkryło z radością, że przemiana wywołana wiarą przynosi głębokie wyzwolenie, rozkwit i spełnienie. Podejmując ryzyko poddania się temu doświadczeniu odkryliśmy naszą wiarę jako prawdziwą w najgłębszym możliwym sensie.

Podążając za mądrością naszych tradycji religijnych uważamy, że należy obudzić naszą „zdolność” do bycia świadomym boskiego podmiotu. Nie dzieje się tak jednak za sprawą magicznego włącznika. Dla osiągnięcia tego przebudzenia istotne jest szczere uznanie swojej bezsilności. Ludzka zdolność do przeżycia przemieniającego zaproszenia przychodzącego wraz z wiarą jest dziś głęboko uśpiona. Skutkiem tego wśród wykształconych ludzi wiara jest tak bardzo „zamrożona” i czasem przykryta pesymistycznymi przypuszczeniami kosmologicznymi opartymi na nauce. Choć zdolność do doświad- 
czenia wiary uległa atrofii w kulturze scjentyzmu i naukowego naturalizmu, uważamy, że wciąż może zostać przywrócona do życia, gdy tylko zrozumiemy, jak ograniczona jest zdolność nauki do odkrycia głębi rzeczywistości.

\section{KONWERGENCJA}

Wyobraź sobie, że grupa ludzi mówi do ciebie, prezentując inne podejście do zagadnienia relacji między nauka a wiara.

Przedstawiciele przedstawionego wyżej kontrastu potrafią jasno pokazywać różnice między nauką i wiarą oraz między nauką a scjentyzmem. Nie dostrzegają jednak możliwości otwartego i prawdziwego dialogu pomiędzy nauką a wiarą. Warto jest wprowadzać rozróżnienia, ale równie istotne jest pokazanie powiązań. Chcemy podkreślić, że naukowe odkrycia implikują często sposób, w który ludzie wierzący myślą o Bogu. Metoda naukowa sama z siebie oczywiście nie mówi nic o osobowym Bogu, teologia zaś nie może być źródłem wiedzy przyrodniczej. Jednakże odkrycia naukowe zmieniają nasze myślenie o Bogu. Jest to szczególnie prawdziwe w odniesieniu do niedawnego odkrycia przez naukę tego, że wszechświat ma niezwykle długą i wciąż rozwijającą się historię.

Innymi słowy, odkrycia fizyki, astrofizyki czy biologii prowadzą do powstania ważnych pytań o to, czy idea osobowego Boga jest dziś możliwa do przyjęcia. Pytanie o osobowego Boga narzuca się najbardziej wtedy, gdy rozważamy teologiczne implikacje biologii ewolucyjnej. Kwestia teologii i ewolucji będzie podjęta poniżej, tymczasem zaś ograniczymy się do przywołania wątpliwości zgłaszanej dziś przez wielu uczonych ludzi: czy współczesna astrofizyka i kosmologia nie czyni pojęcia osobowego Boga całkowicie bezużytecznym?

Gdy mówimy o „osobowym” Bogu mamy na myśli to, że jest on „zainteresowany" tym, co dzieje się na świecie, w tym w naszym osobistym życiu. Nazywać Boga „osobowym” znaczy też przyjmować, że stworzyciel świata cechuje się nieograniczoną inteligencją, wolnością, miłością, wiernością i troskliwością. „Osobowy Bóg” oznacza też wiele więcej, ale przede wszystkim chodzi o jego zdolność do wchodzenia w głębokie relacje, do troski, miłości, składania i dotrzymywania obietnic. Jeśli istnieje osobowy Bóg, to musi posiadać te cechy w bardzo wysokim lub najwyższym stopniu.

Czy za sprawą Galileusza, Newtona, Darwina, Einsteina, Hubble'a czy Hawkinga nie zawalił się przytulny wszechświat, który w przednaukowych czasach chronił nasze myśli o osobowym Bogu? Nowa historia wszech- 
świata, odkryta przez naukowców, wprawiła w zakłopotanie teologię tradycjonalistycznych wierzących. Aby uniknąć wysiłku, część z nich przyjęła poglądy prezentowane przez zwolenników kontrastu. Inni, szczególnie ci, którzy czytają święte księgi w sposób dosłowny, całkowicie odrzucili nowe odkrycia kosmologiczne i biologiczne. Literalne czytanie ksiąg uznawanych w religiach za święte połączyło teologicznie niedouczonych naukowych naturalistów, takich jak przedstawiciele nowego ateizmu, z ich kreacjonistycznymi przeciwnikami. Literalne intepretowanie Biblii doprowadziło Nowych Ateistów do uznania starożytnych pism za bezużyteczne ze względu na brak w nich odpowiedniej wartości poznawczej na poziomie współczesnej wiedzy naukowej. Biblię - jako przeżytek historii będący świadectwem ludzkiego zacofania - radzili ignorować, ponieważ, jak twierdzi Sam Harris, nie ma ona nic do powiedzenia „o elektryczności czy DNA, ani też o rzeczywistym wieku lub rozmiarze wszechświata" $"$.

Stanowisko konwergencji odrzuca takie rzadko spotykane podejście literalne i poszukuje bardziej zniuansowanego spojrzenia na odniesienie odkryć naukowych do wiary i teologii. Rozważmy na przykład to, że wszechświat rozwijał się prawie 14 miliardów lat do czasu genezy pierwszych ludzi. Naukowi naturaliści oraz biblijni fundamentaliści uznają to za przejawy wyjątkowej straty czasu. Ten niezmiernie długi okres czyni pojęcie osobowego bóstwa, doglądającego kosmicznego rozwoju, trudnym do przyjęcia. Dlaczego osobowy Bóg, jeśli istnieje, miałby pozwolić, by świat tak się zestarzał do czasu pojawienia się ludzi? I dlaczego wszechświat się przestrzennie rozszerza? Czy nasza egzystencja jako bytów osobowych jest tylko przypadkowym dodatkiem do niezmiernie bezosobowego procesu kosmicznej twórczości? Czy natura jako taka nie przeczy idei „osobowego Boga”?

Nie są to całkiem nowe pytania. Pesymistyczni filozofowie okresu starożytnego odbierali wszechświat jako bezosobowy, rządzony przez los lub kapryśne bóstwa pozbawione poczucia słuszności czy sprawiedliwości. Niektóre wschodnie tradycje wciąż utrzymują, że wszystkim rządzi bezosobowe prawo karmy (każdy zbiera to, co posiał). Współcześnie wielu, jeśli nie większość, najbardziej wpływowych intelektualistów sądzi, że świat jest zasadniczo bezrozumny, nieżywy i bez celu. W XVII w. pesymistyczny, choć zarazem wierzący w Boga, filozof Blaise Pascal (1623-1662) miał kłopot z połączeniem Boga Abrahama i Jezusa z ogromem czasu i przestrzeni; bezmiarem, który nauka dopiero zaczynała odkrywać. Gdyby Pascal żył dzisiaj, zapewne przyjąłby stanowisko kontrastu, a jego religijny niepokój byłby

\footnotetext{
${ }^{11}$ Sam Harris, Letter to a Christian Nation (New York: Alfred A. Knopf, 2007), 60-61.
} 
jeszcze większy. Wraz $\mathrm{z}$ postępem $\mathrm{w}$ naukowym poznaniu wszechświata, niebiosa wydają się być coraz bardziej milczące. Dziś nie jest trudno wielu ludziom uwierzyć, że wszechświat jest na wskroś bezosobowy.

Zamiast jednak uciekać od nowych danych naukowych dotyczących rozległości wszechświata w czasie i przestrzeni, przyjmujemy te wielkie odkrycia jako zaproszenie do znacznego poszerzenia przekazanego nam w ramach tradycji religijnych obrazu nieskończenie hojnego i dającego nadzieję Boga. Uważamy, że teologia musi wyrosnąć z przywiązania do charakterystycznej dla czasów przednaukowych idei bóstwa jednej planety. Zmiana ta jednak w żaden sposób nie przekreśla naszych tradycyjnych wierzeń. Wręcz przeciwnie, pozostaje ona wierna tradycyjnemu aksjomatowi teologii, który głosi, Bóg pozostaje zawsze nieskończenie większy niż wszechświat. Deus super major - Bóg jest zawsze większy niż wszystko, co możemy sobie wyobrazić i pojąć. Nieważne jak bardzo rozszerza się świat pojmowany przez naukę - będzie on zawsze mniejszy od nieskończoności przypisywanej Bogu przez wiarę. Postęp w naukowym ujęciu wszechświata widzimy jako zaproszenie do rozwinięcia koncepcji wielkości i hojności Boga, nie zaś do jej porzucenia.

Jak jednak możemy myśleć o nieskończonym Bogu w kategoriach osobowych? Czy w świecie, który tak wielu wykształconym ludziom jawi się jako bezkresny i bezosobowy możemy wciąż zwracać się do Boga na „Ty”? Jeśli istnieje osobowy Bóg, powinien być „zainteresowany” nie tylko ludźmi, ale i catym wszechświatem, który odkrywamy dzięki nauce. Ponadto tradycja abrahamiczna rozumie osobę Boga przede wszystkim w kategoriach składania i dotrzymywanie obietnic. Jak to połączyć ze współczesną naukową wizją przyrody?

Jednym z kluczy do takiego połączenia jest fakt, że wszechświat jawi się jako ciągle niedokończony dramat rozgrywany przez osoby. Każda osoba ma udział w kreatywnym procesie kosmicznym we właściwy sobie, niezastąpiony sposób. W toku kosmicznej historii, rzecz jasna, powstały także inne byty, ale najważniejsze jest to, że wszechświat nigdy nie był istotowo bezosobowy, jak zawężająco ujmują to scjentyści w sposób opisany przez konflikt. Kosmiczny dramat od samego początku zawierał w sobie obietnicę stania się osobową historią i wciąż niesie ze sobą obietnicę pojawienia się w przyszłości nawet bardziej niż do tej pory nieprzewidywalnych i kreatywnych zarazem zdarzeń. Nawet najwcześniejsze etapy historii świata wydają się dziś, w retrospekcji, być tak skonfigurowane, by ułatwić powstanie życia, podmiotowości, ludzkich aspiracji, inteligencji, wolności i osobowości. Nasz 
wszechświat nigdy nie był bezosobowy, zatem nauka nie ma podstaw, by zakładać, że jego pierwotne źródło i podstawa są bezosobowe.

Niniejszy tekst umożliwia osobom reprezentującym konflikt swobodne wyrażanie zastrzeżeń wobec tego, co właśnie zostało wyrażone. Dlatego też dyskusja między nauką i wiarą będzie kontynuowana. W tym miejscu chcemy jasno powiedzieć, że przyroda nie jest według nas bezsensownym zbiorem bytów wiecznie i bezosobowo poruszających się przestrzeni. Jest raczej wielką opowieścią, która musi być odczytywana na różnych poziomach, nie tylko za pomocą ilościowych miar nauki, lecz także z uwzględnieniem dramatycznych motywów podsuwanych przez wiarę. $Z$ jej perspektywy świat jest jeszcze nie w pełni zrealizowaną obietnicą bycia czymś więcej; obietnicą, która może być łatwo powiązana z oczekiwaniami Abrahama ${ }^{12}$.

Jeżeli nauka pokazuje wszechświat jako niedokończony dramat, teologia czyta ten dramat jako podróż w przyszłość, którą Bóg nieustannie czyni nową. Osobowa troska Boga o stworzenie polega między innymi na ofiarowaniu światu przyszłości, której jako zwykli śmiertelnicy nie możemy sobie wyobrazić, ale którą dzięki wolności możemy przyjąć lub odrzucić. Dlatego $\mathrm{w}$ stanowisku konwergencji Bóg jest przyszłością wszechświata. Czy może coś bardziej wskazywać na osobistą opiekę niż otwarcie całemu stworzeniu nowej przyszłości? Ciężko nam wyobrazić sobie bardziej wspaniałomyślny przejaw osobistego zainteresowania światem niż zawarcie w nim, pośród tak wielu istniejących ślepych zaułków, nadziei na stanie się czymś więcej ${ }^{13}$.

Co więcej, szeroko ujawniana przez naukę czasowa i przestrzenna wielkość wszechświata nie jest w stanowisku konwergencji przejawem bezosobowości. Wręcz przeciwnie, ta czasowa i przestrzenna ekspansywność jest istotowo, a nie przypadkowo, powiązana $\mathrm{z}$ możliwością pojawienia się osób $\mathrm{w}$ toku ewolucji. Kosmiczni pesymiści próbują pokazać jak mało ważni są ludzie poprzez zestawienie ich z niewyobrażalnie wielkim i rozciągniętym w czasie wszechświatem. Propagatorzy konfliktu wykorzystują fakt, że od czasów Kopernika nauka bardzo poszerzyła nasze wyobrażenie o wielkości wszechświata, detronizując zarazem człowieka i pomniejszając jego znaczenie. My jednak w stanowisku konwergencji pojmujemy ogrom wszechświata w czasie i przestrzeni nie jako marnotrawstwo, lecz jako dramatyczny prolog oraz kon-

\footnotetext{
${ }^{12}$ Pierre Teilhard de Chardin, How I Believe (New York: Perennial Library, 1969), 42.

${ }^{13}$ Por. Wolfhart Pannenberg, Faith and Reality, trans. John Maxwell (Philadelphia, PA: Westminster Press, 1977); PAnNEnBerg, Toward a Theology of Nature: Essays on Science and Faith (Louisville, KY: Westminster John Knox Press, 1993); Ted Peters, God - The World's Future: Systematic Theology for a New Era, wyd. 2 (Minneapolis, MN: Fortress Press, 2000).
} 
tekst powstania życia, uczuć oraz świadomych i osobowych istot, do których najcenniejszych cech należy zdolność do składania i dotrzymywania obietnic.

Pojawienie się osobowych bytów w świecie, zwłaszcza $\mathrm{z}$ ich drogocenną wolnością, jest nie mniej fascynującą zagadką niż powstanie wszechświata w wyniku Wielkiego Wybuchu. Można powiedzieć, że nowe odkrycia w fizyce i kosmologii dostarczają teologii środków do ożywienia refleksji na temat relacji Boga do świata, którego wielkość była niemożliwa do wyobrażenia w minionych stuleciach. Nowość naukowego pojmowania przyrody jako historii lub dramatu pozwala nam widzieć wszechświat w relacji do „zawsze większego" Boga, którego „osobista” troska o świat wyraża się w wiernym oferowaniu mu możliwości stawania się nowym. Otrzeźwiające przewidywania mówiące o tym, że nasz wszechświat wypełniony życiem osiągnie swój koniec (być może za biliony lat) nie odwodzą nas od wiary w Boga, który zawsze otwiera przed nami ślepe zaułki, dając nam nowe możliwości na przyszłość.

Podsumowując, podczas gdy konflikt widzi ludzi jako osobowe byty zagubione w bezkresnym, bezosobowym wszechświecie, my odczytujemy ten wszechświat jako niedokończony dramat, który od zawsze zawierał w sobie obietnicę pojawienia się umysłu, wolności i osobowości. W tym kontekście, powstanie „podmiotów” jest jednym z najważniejszych składników historii „przedmiotowego” wszechświata.

\section{CZY WIARA JEST KOMPATYBILNA Z EWOLUCJĄ?}

\section{KONFLIKT}

W 1859 r. Charles Darwin (1809-1882) opublikował książkę O pochodzeniu gatunków, prezentując swoją słynną teorię ewolucji. Współcześni biolodzy nie mogą wyjść z podziwu jak dobrze teoria ta funkcjonuje w ostatnich 150 latach. Z naszej perspektywy ważniejsze jest jednak to, że teoria Darwina oznacza ostateczny koniec idei Boga. Oczywiście cała współczesna nauka stanowi cios w wiarę w Boga, ale z Darwinem w pozycji lidera prowadzimy decydującą bitwę $\mathrm{z}$ religijnym zabobonem. Ewolucja to nasza ostateczna broń w walce nauki z wiarą i teologią ${ }^{14}$.

\footnotetext{
${ }^{14}$ Dwa najwyraźniejsze przykłady takiego stanowiska znaleźć można w: Jerry A. CoYNe, Why Evolution Is True (New York: Viking, 2009) oraz Richard Dawkins, The God Delusion (New York: Houghton Mifflin, 2006).
} 
Nawet pobieżne spojrzenie na wielkie odkrycie Darwina pozwala zrozumieć, dlaczego uważamy, że ewolucja wyklucza istnienie Boga. W książce O pochodzeniu gatunków Darwin zauważył, że nie wszyscy potomkowie żyjących gatunków osiągają dorosłość. Tylko niektóre jednostki potrafią przystosować się do środowiska na tyle dobrze, aby w ciągu swojego życia zdążyć wydać potomstwo. Mechanizm naturalnej selekcji pozwala przetrwać tylko najlepiej przystosowanym. Najlepiej przystosowany organizm to taki, który po prostu ma większą szansę na przetrwanie i reprodukcję niż wiele innych, mniej szczęśliwych jednostek. Wiele organizmów i gatunków przegrało „walkę o byt”, jak to określił Darwin.

Jak ktoś może uczciwie wierzyć w to, że dobre, kochające i inteligentne osobowe bóstwo jest odpowiedzialne za taką jatkę? Przecież dobry stwórca nie mógłby pozostawać obojętnym na los tych wszystkich organizmów, które zginęły w wyniku działania bezosobowej selekcji. W zarysowanej przez Darwina wizji, los najsłabszych organizmów jawi się jako tak bardzo niesprawiedliwy, że idea sprawiedliwego i miłosiernego Boga wydaje się niewiarygodna. Jesteśmy przekonani, że ewolucji nie da się pogodzić z wiarą w osobowego Boga i jego opatrzność.

Chcemy podkreślić, że mimo wyraźnego marnotrawstwa procesu doboru naturalnego, w ciągu długiej ewolucyjnej przygody, bez wsparcia jakiejkolwiek kreatywnej boskiej inteligencji, doszło do powstania niesamowitego bogactwa form życia, milionów gatunków, w tym naszego. Zgadzamy się więc z Darwinem, że ewolucyjna koncepcja życia ma w sobie coś majestatycznego. Tymczasem teologia nie wnosi niczego do tej wspaniałej przygody życia.

Chcemy w jeszcze bardziej zdecydowany sposób podkreślić, dlaczego nasze stanowisko umacnia się dzięki spojrzeniu na życie oczyma Darwina. Podany przez Darwina przepis na ewolucyjne zmiany, obejmujący przypadkowe pojawianie się nowych gatunków w trakcie długiej historii życia, obejmuje trzy, pozbawione śladów boskości, składniki. Są to: przypadki, bezosobowa naturalna selekcja oraz wielkie marnotrawienie czasu.

Po pierwsze - przypadki. Znaczny stopień przypadkowości czy losowości procesów powstawania i ewolucji życia falsyfikuje ideę projektującego bóstwa. $Z$ chemicznego punktu widzenia, powstanie życia było całkowicie przypadkowe, a nie celowo zaplanowane. Co więcej, długa kosmiczna i geologiczna historia jest wypełniona niezmierną liczbą przypadkowych zdarzeń warunkujących powstanie planety przyjaznej życiu. Nasze istnienie zawdzięczamy zarówno prawom przyrody, jak i nieprzewidywalnym kosmicznym zdarzeniom. Dla przykładu, 65 milionów lat temu asteroida uderzyła w pół- 
wysep Jukatan, powodując nagłe ochłodzenie naszej planety, które doprowadziło do wyginięcia dinozaurów i innych prehistorycznych zwierząt. Z drugiej strony, ten kosmiczny przypadek otworzył nowe możliwości rozkwitu przed ssakami, dzięki czemu na dziejowej scenie mogły pojawić się naczelne i ludzie. Skoro więc istnienie naszego własnego gatunku zależy tak bardzo od tak przypadkowych zdarzeń jak uderzenie asteroidy zmieniające bieg przyrodniczej historii, dziwi nas, że tak wielu wykształconych ludzi wciąż wierzy $\mathrm{w}$ inteligentne bóstwo czuwające nad światem. Co więcej, to przypadki, a nie inteligentny projekt, stoją za modyfikacjami (co dziś byśmy nazwali „mutacjami genetycznymi”), które są bazą ewolucyjnych zmian i różnorodności. Jak zatem ktokolwiek może godzić przypadkowość ewolucji z ideą boskiego, inteligentnego stwórcy?

Po drugie, również bezlitosne działanie naturalnej selekcji jest nie do pogodzenia $\mathrm{z}$ wiarą w bożą opatrzność. Koncepcja naturalnej selekcji to największy wkład Darwina w rozwój nauki. Jakkolwiek przed Darwinem inni przyrodnicy domyślali się, że ewolucja życia zachodzi w czasie, Darwina wielkim wkładem pozostaje wyjaśnienie tego jak działa mechanizm niezbędny dla ewolucyjnych zmian. Naturalna selekcja, jak ją nazwał Darwin, wybiera do przeżycia i reprodukcji tylko niewielką część organizmów; tych, którym udało się zaadaptować. W świetle ślepej obojętności i niesprawiedliwości naturalnej selekcji powinno być jasne, jakim problemem dla wiary i teologii jest ewolucja. Podkreślmy, że sam Darwin czuł się coraz bardziej nieswojo $\mathrm{z}$ ideą Boga projektanta i ostatecznie porzucił swoją chrześcijańską wiarę ${ }^{15}$.

Trzecim aspektem trudnym dla teologii jest niezmiennie dużo zmarnowanego czasu, jakiego ewolucja potrzebowała na wytworzenie życia i umysłu. Przez ok. 10 miliardów lat od Wielkiego Wybuchu nie było życia, przynajmniej na Ziemi. Do czasu eksplozji kambryjskiej, do której doszło ponad 500 milionów lat temu, istniały głownie organizmy jednokomórkowe. Jeśli więc Bóg istnieje, dlaczego proces ten był tak powolny? Jeśli Bóg jest stwórcą, dlaczego jego sposób na wytworzenie życia jest o wiele mniej efektywny niż projekty ludzkich inżynierów? Gdyby wszechświat pochodził od inteligentnego bóstwa, proces powstania żywych i inteligentnych istot nie odbywałby się tak długo i tak krętymi drogami. Tak długi czas potrzeby do genezy życia wydaje się większym marnotrawstwem od tego, którego kiedykolwiek dopuścił się ludzki rzemieślnik lub architekt. Co więcej, dlaczego mając tyle czasu stwórca nie osiągnął lepszego rezultatu w postaci lepiej za-

\footnotetext{
${ }^{15}$ Por. John C. Greene, Darwin and the Modern World View (New York: New American Library, 1963), 44.
} 
projektowanych i łatwiej adaptujących się organizmów? Dlaczego w świecie organicznym jest tyle „błędów konstrukcyjnych”? ${ }^{16}$

Ponad pół wieku przed opublikowaniem przez Darwina „O pochodzeniu gatunków”, anglikański duchowny William Paley dowodził, że tylko inteligentny boski projektant może odpowiadać za zdumiewającą złożoność żyjących organizmów i ich niesamowitą zdolność adaptacji do środowiska. Porównał on projekt żywych organizmów do skomplikowanej budowy mechanizmu zegarka. Konkludując twierdził, że jak złożoność budowy zegarka wymaga inteligentnego projektanta, tak musi go mieć jeszcze bardziej skomplikowany system funkcjonowania organizmów żywych. Dla Paleya, inteligentny projektant był $\mathrm{w}$ oczywisty sposób tożsamy $\mathrm{z}$ Bogiem-Stworzycielem, znanym z tradycji abrahamicznych.

Jak jednak zauważa Richard Dawkins, Darwin pokazuje nam, że ,jedynym zegarmistrzem $\mathrm{w}$ przyrodzie są ślepe siły fizyczne - choć działają w pewien bardzo szczególny sposób. Prawdziwy zegarmistrz przewiduje. Projektuje swoje kółka zębate i sprężyny, planuje połączenia między nimi odpowiednio do ich przyszłego zastosowania, jakie widzi w swojej wyobraźni. Natomiast dobór naturalny - odkryty przez Darwina ślepy, bezrozumny i automatyczny proces, o którym wiemy dziś, że stanowi wyjaśnienie zarówno istnienia, jak i pozornej celowości wszystkich form życia działa bez żadnego zamysłu. Nie ma ani rozumu, ani wyobraźni. Nic nie planuje na przyszłość. Nie tworzy wizji, nie przewiduje, nie widzi. Jeśli w ogóle można o nim powiedzieć, że odgrywa w przyrodzie rolę zegarmistrza, to jest to ślepy zegarmistrz" ${ }^{17}$.

Dawkins dodaje, że od czasów Darwina dla wyedukowanego człowieka „ateizm jest w pełni satysfakcjonujący intelektualnie" ${ }^{18}$. Całkowicie zgadzamy się z Dawkinsem oraz tymi wszystkimi, którzy, uważają, że biologii ewolucyjnej nie da się pogodzić $\mathrm{z}$ wiarą religijną.

\section{KONTRAST}

Choć przedstawiciele konfliktu próbują uczynić z Darwina propagatora ateizmu, w rzeczywistości można go co najwyżej uznać za niezbyt przekonanego agnostyka. Nie porzucił on nonszalancko swojego religijnego dziedzictwa. Podczas swojej słynnej podróży morskiej wciąż myślał, by zostać

\footnotetext{
${ }^{16}$ Por. Coyne, Why Evolution Is True, 22.

${ }^{17}$ Richard Dawkins, Ślepy zegarmistrz, czyli jak ewolucja dowodzi, że świat nie zostat zaplanowany, thum. Antoni Hoffman (Warszawa: Państwowy Instytut Wydawniczy, 1994), 27.

${ }^{18}$ Ibid., 28.
} 
anglikańskim duchownym. Po śmierci pochowano go w opactwie westminsterskim niedaleko Isaaca Newtona. Darwin nie zburzył religijnych przekonań ludzi w swojej epoce $\mathrm{w}$ stopniu przypisywanym mu przez przedstawicieli konfliktu. Jego idee nie powinny też niepokoić współczesnych wierzących.

W przeciwieństwie to reprezentantów konfliktu uważamy, że Darwinowska koncepcja życia jest $\mathrm{w}$ pełni kompatybilna $\mathrm{z}$ wiarą i teologią. Nauka i wiara są tak różnymi sposobami ujęcia rzeczywistości, że tak naprawdę nie mogą ze sobą rywalizować. Teoria naturalnej selekcji Darwina nie jest większym zagrożeniem dla wiary niż prawa fizyki czy chemii. Konflikt nie wyrasta z naukowego ujęcia ewolucji, lecz z wprowadzającego w błąd pomieszania teorii ewolucji ze scjentyzmem i naukowym naturalizmem. Ta myląca synteza może być określona mianem ,ewolucyjnego naturalizmu”.

Nie sprzeciwiamy się ewolucji, lecz ewolucyjnemu naturalizmowi. Odrzucamy też antydarwinowskie, pseudoteologiczne teorie kreacjonizmu oraz inteligentnego projektu (inteligent design, ID). Kreacjoniści rozumieją Biblię literalnie uważając, że przekazuje ona „prawdziwą” wiedzę naukową. Księga Rodzaju jest dla nich nie tylko opowieścią religijną, ale także źródłem wiarygodnych danych naukowych. Jeśli biblijne rozumienie życia jest sprzeczne z Darwinowską teorią ewolucji, kreacjoniści zachęcają, by ją odrzucić i przyjąć biblijny przekaz o stworzeniu życia jako prawdę naukową.

My jednak jako zwolennicy kontrastu odrzucamy literalne odczytywanie tekstów biblijnych, ponieważ intencją ich autorów nigdy nie było zapoznawanie czytelnika $\mathrm{z}$ aktualną wiedzą naukową. Jesteśmy zdziwieni, że nie tylko kreacjoniści, lecz także ateistyczni ewolucyjni naturaliści rozumieją Biblię tak, jakby jej zadaniem był przekaz naukowych danych. W ,wojnach o Darwina”, które trwają aż do dziś, jedna strona (kreacjoniści) znajduje w Księdze Rodzaju dobrą naukę, zaś druga (ewolucyjni naturaliści) — złą naukę. Jednakże obie strony błędnie zakładają, że Biblia jest źródłem wiedzy z zakresu nauk przyrodniczych. Naiwny literalizm biblijny prowadzi do podzielanego przez obie strony przekonania o sprzeczności między wiarą a nauką ${ }^{19}$.

Ponieważ teksty biblijne powstały w epoce przednaukowej, nie powinny być nigdy rozumiane lub oceniane w kategoriach właściwych dla współczesnej nauki. Niestety, zarówno kreacjoniści, jak i ewolucyjni naturaliści tacy jak Dawkins, Dennett i inni wyznawcy Nowego Ateizmu przedstawiają ana-

\footnotetext{
${ }^{19}$ Ewolucyjni naukowcy w swoich dialogach z „religią” często zakładają, że teologowie są „kreacjonistami”, nieświadomi tego, iż idea „stworzenia” jest w teologii bardzo zniuansowana. Aby zobaczyć przykład takiego błędu, por. Niles Eldredge, The Monkey Business: A Scientist Looks at Creationism (New York: Washington Square Press, 1982), 132-135.
} 
chroniczne roszczenia wobec Biblii, naiwnie oczekując od niej naukowej wiarygodności. Wbrew temu, jako reprezentanci kontrastu, uważamy niezmiennie, że celem Biblii nie jest przekazywanie wiedzy przyrodniczej, lecz budzenie wiernych do doświadczenia nieskończonego boskiego misterium, do którego nauka nie ma dostępu.

W publicznych dyskusjach dotyczących doniosłości ewolucyjnej biologii dało się ostatnio zauważyć, że zwolennicy inteligentnego projektu połączyli siły z kreacjonistami w walce z głównymi ideami Darwina. Jak kreacjoniści, propagatorzy ID (wywodzący się zwykle spośród konserwatywnych chrześcijan, choć nie zawsze rozumiejących Biblię literalnie) utrzymują, że naturalne przyczyny nie mogły same doprowadzić do powstania niesamowitego bogactwa żywych organizmów i mechanizmów wewnątrzkomórkowych. Zdaniem zwolenników ID, złożoność życia wymaga nadzwyczajnej ingerencji ponadnaturalnej przyczyny. To ponadnaturalne działanie większość osób rzecz jasna wiąże z Bogiem ${ }^{20}$.

Zgadzamy się ze scjentystami, którzy zwracają uwagę na bardziej teologiczny niż przyrodniczy rodzaj wyjaśniania obecny w teorii inteligentnego projektu, dla której nie widzimy uzasadnionego miejsca w dyskursie naukowym i edukacji publicznej. Teoria ID, tak jak kreacjonizm, może być podważona zarówno na polu nauk przyrodniczych, jak i teologii. Po pierwsze, naukowe dowody ewolucji są niezaprzeczalne. Geologia, paleontologia, datowanie radiometryczne, anatomia porównawcza, biogeografia, embriologia, genetyka i inne pola badań dostarczają wystarczających dowodów, by uznać teorię ewolucji za jeden z największych triumfów nauki. Choć biologia ewolucyjna, jak każda dziedzina nauki, ciągle się rozwija, należy uznać dowody potwierdzające ewolucję i wspierać wysiłki na rzecz lepszego wyjaśnienia jej mechanizmów.

Po drugie, kreacjonizm i ID są nie do zaakceptowania nie tylko przez nauki przyrodnicze, lecz także przez teologię. Twierdząc, że Biblia może dostarczyć naukowych informacji o powstaniu i rozwoju życia, kreacjoniści

\footnotetext{
${ }^{20}$ Przykłady koncepcji ID to m.in.: Michael J. BeHE, Darwin's Black Box: The Biochemical Challenge to Evolution (New York: Free Press, 1996); William Dembski, Intelligent Design: The Bridge between Science and Theology (Downers Grove, IL; InterVarsity Press, 1999); DeMBSKI, The Design Inference: Eliminating Chance through Small Probabilities (Cambridge: CUP, 1998); Philipp E. Johnson, Darwin on Trial (Downers Grove, IL: InterVarsity, 1991); James Porter MoreLAND, ed., The Creation Hypothesis: Scientific Evidence for an Intelligent Designer (Downers Grove, IL: InterVarsity Press, 1994); Jonathan Wells, Icons of Evolution: Science or Myth? (Washington, DC: Regnery Publishing, 2000). Przykładem krytyki ID jest Robert T. Pennock, Tower of Babel: The Evidence against the New Creationism (Cambridge, MA: MIT Press, 1999).
} 
stawiają Księgę Rodzaju w jednym szeregu z pracami z dziedziny nauk przyrodniczych, co odwraca uwagę od głębszego sensu tekstów biblijnych. Koncepcja ID jest teologicznie niepoprawna, gdyż próbuje włączyć do nauk przyrodniczych teologiczny sposób wyjaśniania. Ponieważ większość osób wiąże ID z ideą Boga Stworzyciela zawartą w Biblii, należy zauważyć, że teologicznym błędem jest myślenie o Bogu w kategoriach jednej $\mathrm{z}$ wielu naturalnych przyczyn działających w szeregu. Dlatego też kreacjonizm i ID powinny zostać odrzucone, zarówno na gruncie nauk przyrodniczych, jak i teologii.

Jesteśmy świadomi tego, że kreacjonizm oraz ID są reakcją na problemy, jakie wywołuje sposób prezentowania teorii Darwina przez niektórych prominentnych ewolucjonistów. Richard Dawkins, Daniel Dennett, Jerry Coyne, E. O. Wilson, Stephen Jay Gould i wielu innych ewolucjonistów naruszają wiarygodność naukowych dokonań Darwina, nieroztropnie mieszając biologię ewolucyjną ze światopoglądem materialistycznym. Wypaczyli oni prawdziwą naukę przez zamknięcie odkryć Darwina w ciasne ramy tego systemu przekonań, który nazywamy „ewolucyjnym naturalizmem”. Teoria Darwina zostaje w ten sposób zanieczyszczona obcą jej ideologią. Działania te niekonieczne czynią neutralne światopoglądowo odkrycia Darwina całkowicie nieakceptowalnymi teologicznie.

Ewolucyjni naturaliści $\mathrm{z}$ uporem twierdzą, że ewolucja jest $\mathrm{z}$ natury sprzeczna $\mathrm{z}$ wiarą w Boga. W naszej opinii to bezkrytyczne mieszanie nauki i światopoglądu materialistycznego nie mniej godzi w naukę niż kreacjonizm i ID. Dawkins, Coyne i Dennett bezzasadnie stwierdzają, że przyjęcie biologii ewolucyjnej wymaga jednocześnie zaakceptowania materialistycznego ateizmu. Taki mariaż nauki i ateizmu jest sprzeczny z duchem prawdziwej na takiej samej zasadzie jak to występuje przy pomieszaniu nauki z biblijnym kreacjonizmem i ID.

Odpowiadając na to pomieszanie, zauważmy, że nauka musi być niezależna od jakiegokolwiek systemu przekonań, czy to religijnych, czy to naturalistycznych. Mieszanie nauki z jakimkolwiek światopoglądem prowadzi nieuchronnie do błędnego mniemania, że między nauką i wiarą istnieje konflikt. Przyjąwszy jednak prezentowany przez nas sposób myślenia, zawsze można oczyścić przyrodnicze dociekania z wszelkich deformujących je ideologii czy światopoglądów. Naukowcy powinni skupić się na poszukiwaniu dowodów weryfikujących teorię ewolucji, a teologowie na działaniach mających na celu otwieranie ludzi na niemożliwe do całkowitego ujęcia misterium Boga, o którym nauka nie może nic powiedzieć. Ewolucja to nie 
ateizm, lecz czysto naukowa teoria. Tym, co sprzeciwia się wierze w Boga jest nie biologia ewolucyjna, lecz ewolucyjny naturalizm.

Być może zastanawiasz się, jak godzimy z wiarą trzy teologicznie problematyczne składniki Darwinowskiego przepisu na życie: przypadki, naturalną selekcję i długi czas. Poniżej zamieszczamy naszą odpowiedź.

Po pierwsze, bardzo trudno jest precyzyjnie zdefiniować zdarzenie przypadkowe czy losowe. Uważamy, że przypadek oznacza takie zdarzenie, którego naukowcy nie są w stanie połączyć $\mathrm{z}$ dotychczas poukładaną koncepcją przyrody. Choć nie widzimy dziś sensu pewnych zdarzeń, dla Boga mogą go mieć. Tylko on ma na tyle szeroką perspektywę widzenia, aby uchwycić pełną inteligibilność bytów. Żądanie ostatecznego zrozumienia tu i teraz wszystkich zdarzeń jest przejawem buty ze strony śmiertelników. Reprezentując stanowisko konfliktu, nasi przeciwnicy twierdzą, że Boga nie ma, ponieważ ewolucyjne przypadki nie są inteligibilne. Na czym jednak opierają swoje twierdzenie? Pokazaliśmy przecież, że to, co ludzie nazywają „przypadkami”, w szerszej perspektywie może mieć o wiele głębszy sens od tego, który nasze ograniczone zmysły i umysł mogą kiedykolwiek uchwycić.

Stanowisko konfliktu rości sobie prawo do wszechwiedzy, gdy twierdzi, że jeśli coś nie jest sensowne dla nauk przyrodniczych to jest całkowicie bezsensowne. Odpowiadamy na to: nie ma dowodów na to, że nauka może odpowiedzieć na wszelkie pytania dotyczące wszechświata. Można to stwierdzić już po pobieżnym przyjrzeniu się historii nauki, co przyzna większość rzetelnych naukowców. Co więcej, autorytarna deklaracja zwolenników konfliktu, że ewolucja wyklucza istnienie Boga, jest nie do pogodzenia z pokorą i dystansem, jakich wymaga się od otwartych poszukiwań naukowych. My jesteśmy bardziej umiarkowani w ocenie. Uważamy, że „przypadkowość” mutacji genetycznych czy przypisywanie znaczenia asteroidzie to wrażenia wynikające $\mathrm{z}$ ograniczoności perspektywy ludzkiego pojmowania wszechświata. Wiara religijna podpowiada nam, że każdy czysto ludzki punkt widzenia jest zawsze ograniczony niedoskonałością umysłu. To, co w ubogim ludzkim mniemaniu się wydaje dziś nieinteligibilnym przypadkiem, jest w pełni inteligibilne z perspektywy boskiego spojrzenia na świat.

Po drugie, narzekania na okrucieństwo, walkę i cierpienia wywoływane przez proces naturalnej selekcji, absolutnie nie są niczym nowym dla problemu zła, który zawsze stanowił wyzwanie dla wierzących. Osoby szczerze wierzące w Boga dobrze znają lamentacje Hioba, historie prześladowań proroków i ukrzyżowania Jezusa. Są w pełni świadomi historii przemocy i krwi, które przez wieki stanowią doświadczenie ludzi i innych reprezentantów 
przyrody ożywionej. Dlatego okrucieństwo przypisywane działaniu naturalnej selekcji nie jest dla nas większym problemem teologicznym niż prawo grawitacji czy jakikolwiek znany nam przejaw funkcjonowania przyrody.

Wiemy dobrze, że grawitacja czy prawa termodynamiki nie troszczą się o życie jednostki czy przyrodzoną godność osoby bardziej niż naturalna selekcja. Grawitacja oddziałuje tak na dobrych jak i złych, na słabych i na potężnych, co czasem kończy się śmiercią. Mało kto jednak kiedykolwiek twierdził, że grawitacja stanowi przeszkodę dla wiary w Boga. Z podobną wyrozumiałością patrzymy na naturalną selekcję. Przede wszystkim należy pamiętać, że drogi Boże nie są naszymi drogami. Nasze odczuwanie misterium Boga jest zbyt głębokie, aby pozwolić ograniczonym horyzontom nauki na podważenie naszej wiary. Problemy wywoływane przez naukę, zwłaszcza przez teorię Darwina, są dla wierzących wezwaniem do jeszcze głębszego zaufania niezmierzonej głębi mądrości i opatrzności Boga.

Po trzecie, ogrom czasu, jakiego potrzebuje ewolucja, nie stanowi żadnego problemu dla wierzących w Boga Abrahama, Mojżesza, Jezusa i Mahometa. Ten ogrom czasu, jak widzą go ludzie, to ,jeden dzień” u Boga. Dla wiecznego Boga nie ma problemu długotrwałości, tak jak on się nam jawi.

Jak więc widzicie, naszą odpowiedzią na nauki ewolucyjne jest po prostu zaufanie Bogu, pomimo wszelkich pozornych sprzeczności między wiarą a nauką. Ostatecznie wiara nie jest naprawdę głęboka, dopóki nie dokona skoku w nieznane, wbrew pojawiającemu się poczuciu absurdu. Wiara jest zawsze ufnością „pomimo” trudności, które są wyzwaniem dla naszej ograniczonej możliwości zrozumienia. Duński filozof Søren Kierkegaard (18131855), stanowiący jedno z głównych źródeł naszej inspiracji, zwracał uwagę, że obsesyjne poszukiwanie obiektywnej pewności zabijają samą duszę wiary. Szczera wiara jest możliwa tylko w stanie obiektywnej niepewności. Surowość ewolucji współgra ze starodawnym religijnym ujęciem życia jako „szkoły dla duszy”, której lekcje oczyszczają na drodze do osiągnięcia wiecznego życia. Gdyby życie nie niosło żadnych trudności, gdyby ewolucja przynosiła wyłącznie korzyści, czy mielibyśmy kiedykolwiek szansę na rozwój moralny i duchowy? Nie. Na tej samej zasadzie, ludzie wierzący nie powinni zamartwiać się teorią Darwina.

\section{KONWERGENCJA}

Przedstawiciele kontrastu słusznie zdemaskowali ewolucyjny naturalizm jako mieszankę twierdzeń naukowych i przekonań materialistycznych. Ewolucyjny naturalizm nie jest nauką, lecz sztucznym połączeniem materia- 
listycznego ateizmu z nauką. To właśnie ta niepotrzebna mieszanka, a nie nauka sama w sobie, prowadzi wielu ludzi do błędnego przekonania, że Darwin jest wrogiem wiary. Także pokazanie ideologicznych tendencji w kreacjonizmie i ID jest trafnym posunięciem.

Jednakże wielu naukowców i ludzi wiary uzna, że nasi przedmówcy nie wyczerpali możliwości powiązania wiary i teologii ze współczesną biologią. Dlatego jako zwolennicy konwergencji chcemy potraktować ewolucję bardziej poważnie. Nie jest ona pierwszą lepszą teorią naukową, bez której teologia może bez problemów się obyć. Odkrycia Darwina są istotną częścią pisanej na nowo kosmicznej historii, która wyznacza właściwe intelektualne i duchowe ramy dla ujęcia przez wiarę życia, ludzkiej egzystencji i Boga. W naszej opinii, ewolucja okazuje się być dobrem dla teologii, ponieważ intensyfikuje rozumienie wszechświata jako dramatu, który mamy odczytać na wielu poziomach.

Zwolennicy kontrastu niestety nie uzmysłowili sobie w pełni tego, że od czasów Darwina nasze rozumienie przyrody, życia, człowieczeństwa czy Boga już nigdy nie będzie takie, jak wcześniej. Jeśli teologia ma mieć jakiekolwiek znaczenie we współczesnym klimacie intelektualnym, musi być wyrażona na nowo przy wykorzystaniu terminologii ewolucyjnej. Być może powinniśmy przetworzyć teologię $\mathrm{w}$ taki sposób, by była opowiedziana w języku ewolucji. Pozornie niebezpieczne teorie Darwina, Einsteina czy innych, wymagają połączenia teologicznej refleksji z narracyjnym czy dramatycznym rozumieniem natury. Dlatego też prawdziwym problemem nie jest to, czy obecność pewnych ,projektów” w żywych organizmach wskazuje na Boga czy nie. Zarówno ID, jak i ewolucyjny naturalizm, są zbyt skoncentrowane na dociekaniu tego, czy życie spełnia kryteria dobrej ludzkiej inżynierii lub architektury. Dla nas ważniejsza jest kwestia tego, czy po odkryciach Darwina długi dramat życia, opisywany przez ewolucyjne nauki, jest nośnikiem treści, które mogą być użyteczne dla teologicznych rozważań.

Biologia ewolucyjna pozwala nam myśleć o życiu bardziej w kategoriach dramatu niż projektu. Po pierwsze dlatego, że dramat zakłada element przygodności, przypadkowości lub nieprzewidywalności. Jeśli określona sekwencja wydarzeń jest $\mathrm{w}$ pełni zdeterminowana lub przewidywalna od samego początku, nie ma elementu zaskoczenia czy otwartych możliwości, istotnych do snucia opowieści. Po drugie, mimo że dramat musi charakteryzować się ciągłością wątków, które inteligibilnie wiążą poszczególne wydarzenia i epizody, spójność tę można dostrzec dopiero w retrospektywnym ujęciu, tj. przy zakończeniu opowieści. Bez pewnego stopnia spójności i przewidywal- 
ności dramat stałby się pozbawioną właściwego znaczenia serią niepowiązanych scen. Jednakże w przypadku każdej opowieści spójność, inteligibilność czy znaczenie są przynajmniej częściowo niewidoczne aż do samego końca. Tak więc po raz kolejny przypominamy: czytanie historii życia i wszechświata wymaga cierpliwości i milczącego wyczekiwania. Oczekiwanie pewności tu i teraz, połączone $\mathrm{z}$ obsesją na punkcie doskonałości projektu, uniemożliwia odkrycie spójności dramatu życia.

Po trzecie, każdy dramat czy historia wymagają odpowiednio długiego czasu na rozwój wydarzeń. $Z$ teologicznego punktu widzenia, pytania o sens czasu, ewolucji i samego wszechświata są nierozłącznie związane z odwiecznym zaangażowaniem człowieka, by nadać znaczenie biegowi wydarzeń, w tym dramatowi życia.

Zauważmy, że ewolucyjny przepis Darwina zawiera właśnie te trzy elementy, które są konieczne w każdej opowieści: zdarzenia losowe, przewidywalne działanie naturalnej selekcji, odpowiednio długi czas. Darwinowska wizja życia jest dramatyczna i przez to do głębi narracyjna. Biologia ewolucyjna pokazała, że życie jest nie tyle zbiorem interesujących architektonicznie projektów, co dramatem, który doprasza się, aby odczytywać go z poczuciem wyczekiwania. Jego znaczenie w końcu się ujawni, lecz być może dopiero w odległej przyszłości.

To, że życie jest wciąż trwającą opowieścią, a nie ustalonym i ukończonym zbiorem atomów, molekuł i komórek ma znacznie dla teologii. Opowieści to medium, dzięki któremu nasz gatunek zawsze przekazywał pewne istotne prawdy. Od pojawienia się ludzkiej świadomości, intuicje dotyczące rozumienia wszechświata ubierane były w formę opowieści. Poprzez mity, eposy, ballady, dramaty, odyseje i inne formy opowiadania ludzie wyrażali swoje rozumienie tego, co spaja poszczególne wydarzenia. Obecnie to nauka proponuje nam nową wielką narrację, epos o ewolucji, stanowiący część większego kosmicznego dramatu. Ta narracja domaga się jednak odczytywania syntetycznego, a nie analitycznego. Czytanie tej opowieści oznacza poszukiwanie jej spójności, nie zaś mechanicznej czy architektonicznej elegancji. Tak więc $\mathrm{w}$ interakcji pomiędzy teologią a naukami przyrodniczymi pierwszorzędną kwestią w odniesieniu do ewolucji nie jest pytanie o projekt, które jawi się jako atrakcyjne w wąskiej perspektywie badań podejmowanych przez ewolucyjnych naturalistów i zwolenników ID. My natomiast proponujemy, aby w dramacie wszechświata szukać przede wszystkim religijnego znaczenia. Skupienie się tylko na projekcie, jak to czynią ewolucyjni naturaliści i zwolennicy ID, jest dla teologii ślepym zaułkiem. 
Poza tym, zupełnie nie zadawala nas stanowisko reprezentantów kontrastu mówiące, że przypadków być może w ogóle nie ma lub że ich rozpoznanie wynika jedynie z tego, że nie mamy pełnej wiedzy o boskim planie. Naszym zdaniem przypadki w ewolucji i historii naturalnej są całkowicie realne faktem i dramatycznie konieczne. Przypadkowość, spontaniczność, nieprzewidywalność to nieodzowne elementy każdego prawdziwego dramatu, w tym dramatu życia. Przypadek nie jest ani absurdem, jak sugeruje konflikt, ani iluzją, jak sądzi kontrast. Przypadek w ewolucji jest niezbędny, by życie było tym, czym jest dramat. $\mathrm{Z}$ teologicznego punktu widzenia, istnienie przypadku jest tym, czego powinniśmy oczekiwać, by historia życia była spójna z naszą wiarą w spełnienie obietnic troskliwego Boga, dzięki któremu przyszłość jest otwarta. Jeśli Bóg jest nieskończoną miłością, jak utrzymuje nasza tradycja religijna, musimy pamiętać, że miłość do niczego nie przymusza, ale pozwala kochanej osobie być i pozostać sobą. Dlatego Bóg dał stworzeniu, życiu i ludzkiej historii przestrzeń na niezdeterminowaną spontaniczność, ludziom zaś wolność do samodzielnego życia oraz - przynajmniej względnej — autodeterminacji.

Bóg troszczy się o dobro świata, ale w naszym rozumieniu oznacza ono posiadanie czasu i przestrzeni do stania się czymś innym niż Bóg. Tradycje abrahamiczne zgadzają się co do tego, że stworzenie musi być różne od stwórcy. W przeciwnym wypadku stworzenie byłoby tylko przedłużeniem boskiego bytu, a w konsekwencji nie byłoby w ogóle stworzeniem. W takim ujęciu nie byłoby świata istniejącego oddzielnie od stwórcy. Istnienie świata różnego od Boga wymaga zatem, by świat posiadał pewną swobodę, której nie ma perfekcyjnie zaprojektowany obiekt.

Przypadkowość i obecność otwartych możliwości w ewolucji są spójne z przekonaniem o tym, że życie to bardziej dramat niż dopracowany zbiór projektów. Gdyby Bóg był dyktatorem czy nadzorcą, moglibyśmy spodziewać się, że przebieg historii świata już w chwili jego magicznego zaistnienia będzie zaplanowany $\mathrm{w}$ najdrobniejszych szczegółach. Powinniśmy zatem oczekiwać, że taki perfekcyjnie zaplanowany świat z biegiem czasu pozostanie zasadniczo niezmienny. Gdyby Bóg był nadzorującym świat inżynierem, kontrolującym wszystko, jak chcą przedstawiciele konfliktu, nie powinniśmy oczekiwać, że zaistnieje tak wiele dziwnych organizmów, które dramat życia rzucił na scenę historii, jak to poznaliśmy dzięki szczegółowym odkryciom geologii i biologii. Powinniśmy oczekiwać, że boski architekt z naszych wyidealizowanych wyobrażeń nie będzie stwarzać dziwacznych stworzeń z czasów eksplozji kambryjskiej, dinozaurów i gadów, czy też wielu innych form 
życia, które wydają się nie pasować do naszego ograniczonego w ludzki sposób wyobrażenia dobrego projektu. Wolelibyśmy przecież, aby boski magik raz a dobrze skonstruował świat ożywiony, zgodnie z naszymi własnymi wzorcami perfekcji.

Jakże blady byłby świat opisany powyżej w porównaniu z tym, w którym żyjemy. Nasze tęsknoty za stworzeniem ukończonego od razu wszechświata byłyby zarazem wykluczeniem dramatu, różnorodności, przygody, piękna owszem, także tragedii - które są dziełem ewolucji. Doskonale zaplanowany kosmos byłby bardziej uporządkowany niż ten, w którym żyjemy, i w harmonii, ale nie miałby $\mathrm{w}$ sobie nic ze wspaniałości dramatu, postrzeganego przez Darwina podczas jego badań nad życiem jako pociągające misterium.

W naszym przekonaniu Bóg jest nie magikiem, ale stwórcą ${ }^{21}$, który woli wolność, przygodę i dramat od zamrożenia w punkcie wyjścia wszystkiego, co istnieje, w odwiecznym i nienaruszalnym porządku. Ponieważ Bóg najwyraźniej kocha różne historie, dziwne i pogmatwane ścieżki ewolucji nie są dla nas zaskoczeniem. Długi dramat wszechświata, potrzebujący czasu, by zaowocować powstaniem życia, inteligencji, osobowości, pragnień moralnych i tęsknot religijnych dobrze współgra z naszą wiarą w to, że prawdziwie troskliwa miłość nigdy nie przymusza, ale zawsze podejmuje ryzyko i pozwala na spontaniczność, niespodziankę, wolność i przygodę.

Półtora wieku po opublikowaniu „O pochodzeniu gatunków” naukowcy wciąż dokonują odkryć przyrodniczych, które trudno pogodzić z naiwnym pojęciem boskiego projektu. Świat żywych organizmów nie ma w sobie perfekcji zaprojektowanego mechanizmu, jak oczekują tego zwolennicy ID. Stosunkowo niedawne odkrycia ukazujące szczegóły wciąż trwającej kosmicznej historii, w tym dramat ewolucji życia, bardzo dobrze pasują do obrazu dającej siebie twórczej miłości oraz obietnic Boga, o którym mówią tradycje religijne. Bóg wzywa nie tylko Abrahama, ale cały wszechświat do wchodzenia w nową przyszłość. To otwieranie przyszłości przez Boga jest ostatecznym teologicznym wyjaśnieniem ewolucji. Co więcej, Bóg w zaskakujący i hojny sposób zaprasza nie tylko ludzi, ale wszelkie stworzenia, do udziału w dziele stworzenia. Bóg daje stworzeniom ważną rolę, czyniąc je partnerami w rozgrywającym się dramacie stworzenia. Bóg całkowicie rezygnuje z możliwości doskonałego inżyniersko i architektonicznie zaprojektowania stworzenia raz na zawsze. Zamykałoby to przed światem możliwość autentycznej przyszłości. Wykluczałoby to zarazem możliwość pojawienia się ludzkiej wolności.

\footnotetext{
${ }^{21}$ Por. L. Charles BIRCH, Nature and God (Philadelphia, PA: Westminster, 1965), 103.
} 
W naszej ocenie historia wiary jest także częścią większego dramatu życia na ziemi. Wiara to usiłowanie dostosowania się świadomych, osobowych bytów do ich ostatecznego środowiska, do nieskończonego misterium Boga. Ponieważ to nieskończone misterium wymyka się możliwości całkowitego zrozumienia, religia nigdy nie wyrazi go w pełni. Dlatego też w naszych próbach dostosowania się do naszego ostatecznego środowiska zawsze będzie obecne zniecierpliwienie, uporczywa niezgoda na religijne i teologiczne status quo, może nawet pewna forma „ateizmu”. Religie także podlegają pewnej selekcji ewolucyjnej i cyklom życiowym. Uważamy, że to nasze ostateczne środowisko, które określamy „Bogiem”, nieustannie przesiewa, porządkuje, i "sądzi” nasze religijne symbole i mity, pozwalając na odejście do lamusa wszystkich tych religijnych wyobrażeń, które nie odpowiadają niewyczerpanej wolności, przyszłości i miłości.

Prawdziwy ateizm, który jest różny od jego płytkich współczesnych odmian opartych na wewnętrznie sprzecznym scjentyzmie, jest częścią przygody, która prowadzi do odrzucenia błędnych obrazów Boga. Uważamy zatem, że zgiełkliwy często dramat wiary na Ziemi i całe to błądzenie życia po ścieżkach ewolucji, dobrze współgrają z obecnym w religiach abrahamicznych obrazem podejmującego ryzyko i kochającego Boga, „który czyni wszystko nowe",22. Ciężko byłoby nam pogodzić wiarę w Boga obietnicy i nieskończonej miłości z istnieniem wszechświata innego, niż ten, który opisuje Darwinowska koncepcja ewoluującego życia.

Z języka angielskiego przełożyli

Maksymilian Kuźmicz i Marek Stomka

\section{BIBLIOGRAFIA}

BeHE, Michael J. Darwin's Black Box: The Biochemical Challenge to Evolution. New York: Free Press, 1996.

BIRCH, Charles. Nature and God. Philadelphia, PA: Westminster, 1965.

Coyne, Jerry A. Why Evolution Is True. New York: Viking, 2009.

\footnotetext{
${ }^{22}$ Rozwój tych idei można zobaczyć m.in. w: John F. Haught, The Cosmic Adventure (New York: Paulist Press, 1984); Haught, The Promise of Nature: Ecology and Cosmic Purpose (New York-Mahwah, NJ: Paulist Press, 1993); Haught, God after Darwin: A Theology of Evolution (Boulder, CO: Westview, 1999); HaUght, Making Sense of Evolution (Louisville, KY: Westminster John Knox Press, 2010).
} 
DAwKIns, Richard. „Tanner Lecture on Human Values”. Wykład wygłoszony na Harvard University, 19-20.11.2003.

DawkIns, Richard. Ślepy zegarmistrz czyli jak ewolucja dowodzi, że świat nie został zaplanowany. Tłum. Antoni Hoffman. Warszawa: Państwowy Instytut Wydawniczy, 1994.

DawkIns, Richard. The God Delusion. New York: Houghton Mifflin, 2006.

Dembski, William. Intelligent Design: The Bridge between Science and Theology. Downers Grove, IL: InterVarsity Press, 1999.

Dembski, William. The Design Inference: Eliminating Chance through Small Probabilities. Cambridge: CUP, 1998.

Dennet, Daniel C. Consciousness Explained. New York: Little, Brown and Co., 1991.

Einstein, Albert. Ideas and Opinions. New York: Crown Publishers, 1954.

Eldredge, Niles. The Monkey Business: A Scientist Looks at Creationism. New York: Washington Square Press, 1982.

Greene, John C. Darwin and the Modern World View. New York: New American Library, 1963.

Hardwick, Charley. Events of Grace: Naturalism, Existentialism, and Theology. Cambridge: CUP, 1996.

Harris, Sam. Letter to a Christian Nation. New York: Alfred A. Knopf, 2007.

Haught, John F. God after Darwin: A Theology of Evolution. Boulder, CO: Westview, 1999.

Haught, John F. Making Sense of Evolution. Louisville, KY: Westminster John Knox Press, 2010.

Haught, John F. Science and Faith: A New Introduction. New York-Mahwah, NJ: Paulist Press, 2012.

Haught, John F. The Cosmic Adventure. New York: Paulist Press, 1984.

Haught, John F. The Promise of Nature: Ecology and Cosmic Purpose. New York-Mahwah, NJ: Paulist Press, 1993.

Hawking, Stephen, and Leonard Mlodinow. The Grand Design. New York: Bantam Books, 2010.

Johnson, Philipp E. Darwin on Trial. Downers Grove, IL: InterVarsity, 1991.

Moreland, James Porter, ed. The Creation Hypothesis: Scientific Evidence for an Intelligent Designer. Downers Grove, IL: InterVarsity Press, 1994.

Moser, Paul K. The Elusive God: Reorienting Religious Epistemology. New York: CUP, 2008.

Pannenberg, Wolfhart. Faith and Reality. Tłum. John Maxwell. Philadelphia: Westminster Press, 1977.

Pannenberg, Wolfhart. Toward a Theology of Nature: Essays on Science and Faith. Louisville, KY: Westminster John Knox Press, 1993.

Peters, Ted. God - The World's Future: Systematic Theology for a New Era. Wyd. 2. Minneapolis, MN: Fortress Press, 2000.

Rosenberg, Alex. „Why I Am a Naturalist”. New York Times, 17.09.2011.

Teilhard de Chardin, Pierre. How I Believe. New York: Perennial Library, 1969.

Weinberg, Stephen. Dreams of a Final Theory. New York: Pantheon Books, 1992.

Wells, Jonathan. Icons of Evolution: Science or Myth? Washington, DC: Regnery Publishing, 2000. PENNOCK, Robert T. Tower of Babel: The Evidence against the New Creationism. Cambridge, MA: MIT Press, 1999. 


\title{
CZY NAUKA WYKLUCZA ISTNIENIE OSOBOWEGO BOGA \\ I CZY WIARA W NIEGO JEST KOMPATYBILNA Z EWOLUCJĄ?
}

\author{
Streszczenie
}

Ten tekst przedstawia trzy różne sposoby, w jakie ludzie, którzy mieli kontakt z nauką, odpowiadają na następujące pytania: „Czy nauka jest zgodna z wiarą religijną?” oraz „Czy nauka nie wyklucza istnienia osobowego Boga?”. Pierwsza odpowiedź zakłada, że nauki przyrodnicze i wiara religijna wykluczają się wzajemnie. To jest sytuacja konfliktu. Jej przedstawiciele należą do dwóch głównych podgrup: (1) sceptyków, którzy wierzą, że nauki przyrodnicze uczyniły wszystkie twierdzenia religijne niewiarygodnymi, oraz (2) ludzi wiary, którzy odmawiają przyjęcia pewnych naukowych idei, takich jak kosmologia Wielkiego Wybuchu i ewolucja biologiczna. W obecnym tekście konflikt dotyczy tylko naukowych sceptyków, którzy twierdzą, że metody i odkrycia naukowe zdezaktualizowały wiarę religijną i teologię.

Drugi typ odpowiedzi na wymienione pytania utrzymuje, że nauka i wiara dotyczą różnych poziomów lub wymiarów rzeczywistości. Zgodnie z tym podejściem, nauka i teologia stawiają zupełnie inne rodzaje pytań, dlatego nie można ich traktować jako konkurencyjnych obszarów. W stanowisku kontrastu podkreśla się, że nie może być prawdziwego konfliktu między twierdzeniami nauk przyrodniczych a twierdzeniami wiary i teologii. Wiara i nauka nie rywalizują o jakiś wspólny cel, więc nie mogą wchodzić ze sobą w konflikt.

Trzecim stanowiskiem jest konwergencja. Można je również nazwać „współbrzmieniem”, „współpracą”, „kontaktem” lub „konwersacją”. To stanowisko zgadza się z tezą „kontrastu”, według którego wiara religijna i nauki przyrodnicze są różnymi sposobami rozumienia świata, ale argumentuje zarazem, że te dwa obszary nieuchronnie oddziałują na siebie. Konwergencja promuje tę interakcję. Celem zwolenników konwergencji jest osiągnięcie syntezy, w której zarówno nauka, jak i wiara zachowują swoją tożsamość, a jednocześnie pozostają w ścisłym związku ze sobą we wspólnym dążeniu do inteligibilności i prawdy. Konwergencja zakłada, że odkrycia naukowe mają znaczenie dla wiary, innymi słowy, odkrycia naukowe mogą znacząco wpłynąć na to, jak myślimy o Bogu i sensie naszego życia. Konwergencja zakłada, że nauka i wiara, o ile nie są ze sobą mylone, mogą razem prowadzić do bogatszego spojrzenia na rzeczywistość.

Słowa kluczowe: nauka; wiara religijna; konflikt; kontrast; konwergencja.

\section{DOES SCIENCE RULE OUT A PERSONAL GOD? IS FAITH COMPATIBLE WITH EVOLUTION?}

\section{Su m m a ry}

This text lays out three distinct ways in which people who have been exposed to science are now responding to the following questions: "Does science rule out a personal God?" and "Is faith compatible with evolution?" The first kind of response claims that the natural sciences and religious faith are mutually exclusive. This is the conflict position. Its representatives include two main subgroups: (1) skeptics who believe that the natural sciences have made all religious claims unbelievable, and (2) people of faith who refuse to accept certain scientific ideas such as Big Bang cosmology and biological evolution. However, in the present text conflict refers only to scientific skeptics, those who claim that scientific method and discoveries now make religious faith and theology obsolete.

A second type of response to the questions listed claims that science and faith are each concerned with different levels or dimensions of reality. Science and theology, according to this ap- 
proach, ask completely different kinds of questions, and so it makes no sense to place them in competition with each other. The contrast approach, as we call it, maintains that there can be no real conflict between the claims of natural science and those of faith and theology. Contrast insists that faith and science are not competing for some common goal, so they cannot come into conflict with each other.

A third approach is that of convergence. It might also be called "consonance," "cooperation," "contact," or "conversation." Convergence agrees with the contrast approach that religious faith and natural science are distinct ways of understanding the world, but it argues that the two inevitably interact. Convergence promotes this interaction. Its objective is to arrive at a synthesis in which both science and faith keep their respective identities while still relating closely to each other in a shared pursuit of intelligibility and truth. Convergence assumes that scientific discoveries matter to faith. In other words, scientific findings can make a significant difference in how we think about God and the meaning of our lives. Convergence wagers that science and faith, as long as they are not confused with each other, can together continue to a richer view of reality than either can achieve on its own.

Keywords: science; religious faith; conflict; contrast; convergence. 